\title{
KETIDAKSETARAAN GENDER BIDANG PENDIDIKAN: FAKTOR PENYEBAB, DAMPAK, DAN SOLUSI
}

\author{
Harum Natasha \\ Fakultas Tarbiyah dan Keguruan Universitas Islam Negeri Sultan Syarif Kasim Riau
}

\begin{abstract}
It is undeniable that gender inequality still occurs especially in the developing world. This inequity occurs in various fields of human life, among others in the fields of education, social, and economic. Gender inequality that occurs mainly in the field of education is influenced by various factors: cultural factors, patriarchy, sociology and psychology. The imbalance also affects the life of the nation and the state. To that end, this study discusses the factors that cause the occurrence of gender inequality and the impact that would occur if gender inequalities allowed to drag and solutions that are expected to be applied so that gender inequality can be reduced or even eliminated.
\end{abstract}

Keyword: gender inequality, education, causes, impact

\begin{abstract}
A bstrak: Tidak bisa dipungkiri bahwa ketidaksetaraan gender masih saja terjadi terutama di negara-negara yang sedang berkembang. Ketidak setaraan ini terjadi di berbagai bidang kehidupan manusia, antara lain di bidang pendidikan, sosial, dan ekonomi. Ketidaksetaraan gender yang terjadi terutama dibidang pendidikan dipengaruhi oleh berbagai macam faktor yaitu faktor budaya, patriaki, sosiologi dan psikologi. Ketidak seimbangan tersebut juga berdampak terhadap kehidupan bangsa dan negara. Untuk itu, penelitian ini mendiskusikan tentang faktorfaktor penyebab terjadinya ketidaksetaraan gender dan dampak yang akan terjadi jika ketidak setaraan gender dibiarkan berlarut-larut serta solusi yang diharapkan dapat diaplikasikan sehingga ketidaksetaraan gender dapat dikurangi atau bahkan dihapuskan.
\end{abstract}

Kata K unci: Ketidaksetaraan gender, pendidikan, penyebab, dampak

\section{PENDAHULUAN}

Pendidikan yang dahulunya merupakan hal yang langka di kehidupan masyarakat Indonesia, kini semakin diketahui urgensinya bagi kemajuan bangsa. Pendidikan dianggap sebagai pengubah kejiwaan manusia atau yang lebih dikenal sebagai memanusiakan manusia. Pendidikan juga merupakan langkah awal untuk mempersiapkan manusia menjalani dunia kerja maupun dunia bermasyarakat. Ada beberapa pengertian pendidikan menurut para ahli yang tercantum di dalam buku Filsafat Pendidikan karya Yunus ${ }^{1}$, diantaranya menurut Prof. Herman $\mathrm{H}$. Horn, yang mengatakan "Pendidikan adalah proses abadi dari penyesuaian lebih tinggi bagi makhluk yang telah berkembang secara fisk dan mental yang bebas dan sadar kepada Tuhan seperti termanifestasikan dalam alam sekitar, intelektual, emosional dan kemauan dari manusia." Pendapat lain dikemukakan oleh M.J. Langeveld yang menyatakan "Pendidikan adalah setiap pergaulan yang terjadi antara orang dewasa dengan anak-anak merupakan lapangan atau suatu keadaan dimana pekerjaan mendidik itu berlangsung." Prof. 
Dr. John Dewey menyatakan "Pendidikan adalah suatu proses pengalaman. Karena kehidupan adalah pertumbuhan, pendidikan berarti membantu pertumbuhan batin tanpa dibatasi oleh usia. Proses pertumbuhan ialah proses menyesuaikan pada tiap-tiap fase serta menambahkan kecakapan di dalam perkembangan seseorang." Sedangkan Prof. H. Mahmud Yunus berpendapat bahwa "Pendidikan adalah usaha-usaha yang sengaja dipilih untuk memengaruhi dan membantu anak dengan tujuan peningkatan keilmuan, jasmani dan akhlak sehingga secara bertahap dapat mengantarkan si anak kepadatujuannya yang paling tinggi. Agar si anak hidup bahagia, serta seluruh apa yang dilakukanya menjadi bermanfaat bagi dirinya dan masyarakat."

Sedangkan menurut Undang-undang no 12 tahun 2012 menyatakan bahwa: Pendidikan adalah usaha sadar dan terencana untuk mewujudkan suasana belajar dan proses pembelajaran agar peserta didik secara aktif mengembangkan potensi dirinya untuk memiliki kekuatan spiritual keagamaan, pengendalian diri, kepribadian, kecerdasan, akhlak mulia serta keterampilan yang diperlukan dirinya, masyarakat, bangsa dan negara. $^{2}$

Dari pengertian yang dipaparkan diatas jelas bahwa pendidikan diharapkan mampu mengubah seseorang menjadi perilaku yang dapat melejitkan kemampuan dirinya di segalalini kehidupan. Dari sebuah pendidikan diharapkan manusia tersebut memiliki keahlian, keterampilan serta akhlak mulia yang dapat menjadi bekal baginya dalam meniti kehidupan. Kelak ketika ia menjadi panutan sebagai orang tua, mampu mendidik anak-anaknya sebagai penerus generasi berikutnya.
Sehubungan dengan itu, jalur pendidikan yang diawali dari rumah menjadi sebuah starting level bagi seorang anak untuk menjadi berpotensi seperti ditargetkan oleh undangundang di atas. Oleh karenanya, seorang ibu idealnya memiliki pendidikan yang memadai demi berkembangnya kemampuan dan keterampilan seorang anak. Maka, pendidikan bagi perempuan adalah sebuah kemestian. Pepatah lama mengatakan, keberhasilan suatu bangsa tergantung kepada wanitanya. Wanita-wanita yang cerdas tentu akan melahirkan anak-anak penerus bangsa yang cerdas pula. Bahwa pendidikan bagi seorang perempuan merupakan hal yang krusial demi mewujudkan bangsa yang lebih baik.

\section{Sayangnya, P.Todaro ${ }^{3}$ menyatakan} bahwa di hampir setiap negara berkembangtermasuk Indonesia-anak perempuan

menerima pendidikan yang jauh lebih sedikit dibandingkan anak laki-laki. Tercatat di 66 dari 108 negara, jumlah anak perempuan setidaknya berkisar 10 persen, dibandingkan dengan jumlah anak laki-laki. Adanya istilah educational gender gap atau kesenjangan pendidikan antargender yang paling tinggi ditemukan di negara-negara termiskin sedangkan secara regional tersebar di Timur Tengah dan Afrika Utara. Lebih Ianjut ia mengemukakan bahwa kemampuan anak perempuan dalam baca tulis lebih rendah 29 persen dibandingkan dengan anak lakilaki. Meski ada kemajuan, namun tetap terjadi kesenjangan yang nyata antara anak perempuan dan anak laki-laki.

Sementara, fakta dari UN ICEF menyatakan bahwa data dari Departemen Pendidikan terdapat kesenjangan pendidikan antara anak laki-laki dan perempuan. ${ }^{4}$ Dari 10 anak yang putus sekolah di tingkat Sekolah Dasar terdapat enam anak perempuan dan empat 
anak laki-laki. Sedangkan padatingkatSekolah Menengah Pertama dari 10 anak yang putus sekolah terdapat 7 anak perempuan dan 3anak laki-laki. ${ }^{5}$ Data ini jelas membuktikan adanya ketidakseimbangan tingkat pendidikan antara anak perempuan dan anak laki-laki.

Sebuah rangkuman Bank Dunia tentang Pembangunan BerspektifGender ${ }^{6}$ menyatakan bahwa ketidaksetaraan gender di bidang pendidikan dan kesehatan banyak terjadi di kalangan masyarakat miskin. Di negaranegara berkembang yang berpenghasilan rendah, terjadi penurunan angka pendaftaran ke sekolah-sekolah. Hal ini tentu sungguh sangat disayangkan, karena akan memberikan pengaruh yang tidak baik di negara-negara yang sedang berkembang ini.

Dipandang dari sudut ekonomis, pendidikan untuk perempuan dianggap penting dikarenakan oleh empat alasan. ${ }^{7}$ Pertama, tingkat pengembalian atau rate of return dari pendidikankaumwanitalebihtinggi dari pada tingkat pengembalian pendidikan pria di kebanyakan negara berkembang. Kedua, adanya peningkatan pendidikan pada kaum wanita menaikkan produktivitas di lahan pertanian dan juga meningkatkan partisipasi tenaga kerja, pernikahan yang lebih lambat, fertilitas yang lebih rendah dan juga perbaikan kesehatan dan gizi anakanak. Ketiga, kesehatan dan gizi anak-anak yang lebih baik serta ibu yang lebih terdidik akan memberikan dampak pengganda atau multiplier effect terhadap kualitas anak bangsa sel ama beberapa generasi ke depan. Keempat, karena kaum wanita memikul beban terbesar dari kemiskinan dankelangkaan lahangarapan yang adadi masyarakat di negara berkembang, maka perbaikan yang signifikan dalam peran dan status wanita melalui pendidikan akan mempunyai dampak yang penting dalam memutus lingkaran setan kemiskinan serta pendidikan yang tidak memadai.

Fakta ini tentu merupakan realita yang menuntut penulis untuk lebih jauh mencari tahu, apakahfaktor-faktor penyebabterjadinya ketidaksetaraan gender yang adakhususnyadi Indonesia? A pakah dampak yang akan terjadi jika ketidaksetaraan gender ini tidak segera dicari solusinya? Serta apakah solusi yang terbaik untuk setidaknya mengurangi angka ketertinggal an anak perempuan dibandingkan anak laki-laki di bidang pendidikan?

\section{METODE PENELITIAN}

Penelitian ini termasuk ke dalam penelitian kualitatif. Metode kualitatif melibatkan kumpulan anal isis data non angka yang didapatkan dari observasi, interview, rekaman, dokumen, dan semacamnya. ${ }^{8}$ Gay menyatakan bahwa penelitian dengan metode kualitatif mendefenisikan masalah atau pertanyaan penelitian dengan melakukan pendekatan interpretif untuk menarasikan gambaran variabel dan konteksnya.

\section{Sedangkan Cresswell ${ }^{9}$ menyatakan} bahwa metode penelitian kualitatif adalah suatu proses penelitian dan pemahaman yang berdasarkan pada metodologi yang menyelidiki suatu fenomena sosial dan masal ah manusia. Pada penelitian ini, peneliti membuat suatu gambaran kompleks, meneliti kata-kata, laporan terinci dari pandangan responden, dan melakukan studi pada situasi yang dialami.

Seperti dijelaskan di atas, maka penelitian ini menggunakan metode kualitatif dengan pendekatan kepustakaan yang akan membuat deskripsi atau gambaran tentang ketidaksetaraan pendidikan perempuan dengan laki-laki. Faktor-faktor penyebab 
terjadinya ketidaksetaraan pendidikan pada perempuan, dampak yang akan muncul, serta solusi yang terbaik untuk menanggulangi permasalahan ini.

\section{HASIL PENELITIAN DAN PEM BAHASAN}

Secara filosofis, sebenarnya setiap warganegara Indonesia dilindungi dan dijamin dari sikap dan tindakan diskriminatif tanpa membeda-bedakan suku, agama, ras, dan jenis kelamin.. Hal ini termaktub di dalam UUD 1945 Pasal 28 ayat 1 yang menyata kan bahwa: “" Setiap orang berhak bebas dari perlakuan yang bersifat diskriminatif atas dasar apapun dan berhak mendapatkan perlindungan terhadap perlakuan yang bersifat diskriminatif itu." Namun pada kenyataannya, ketidaksetaraan gender, yang menyinggung atau membeda-bedakan seseorang berdasarkan jenis kelaminnya, masih saja terjadi di kalangan masyarakat kita. Ketidaksetaraan gender terjadi di berbagai bidang kehidupan di belahan negara-negara di dunia. ${ }^{10}$ Meski ada kemajuan dalam peningkatan angka kesenjangan antara perempuan dan laki-laki, namun sifat dan tingkat diskriminasi masih bersifat variatif di wilayah-wilayah tertentu. Berbagai pihak baik perempuan maupun anak-anak akan menanggung beban akan kesenjangan yang terjadi khususnya dibidang pendidikan. N amun sebenarnya, beban atau dampak yang akan terjadi merupakan sebuah kerugian bagi semua pihak.

Sebuah artikel menyatakan ada berbagai macamketidakadilanyang dialami perempuan yang dikategorikan sebagai berikut ${ }^{11}$ :

\section{Stereotyping}

Stereotype atau labeling yang melekat pada diri perempuan biasanya berbau negatif seperti lemah, penakut, cengeng, dan sebagainya memunculkan perbedaan dengan anak laki-laki yang diberi labe kuat, pemberani, tabah.

2. Subordinasi yaitu adanya perilaku menomorduakan anak perempuan hampir di segala bidang, hingga perempuan ditempatkan sebagai posisi yang lebih rendah.

3. Marginalisasi yaitu terpinggirkannya kaum perempuan yang kebanyakan terjadi dibidang ekonomi dimana

perempuan dianggap bukan seorang tulang punggung keluarga sehingga mendapatkan pendapatan yang lebih rendah, serta melakukan pekerjaan yang hanya bersifat teknis dan rutinitas saja.

4. Double burden dialami oleh wanita karier dimana tidak saja mengurusi pekerjanpekerjaan rumah tangga namun juga berperan ganda memikirkan pekerjaan karirnya.

5. Kekerasan (violence) yaitu kekerasan yang terjadi pada diri perempuan baik secara fisik maupun psikis.

Hal-hal tersebut diatas merupakan ketidakadilan yang dibebankan kepada kaum perempuan sehingga kaum perempuan menjadi termarjinalkan dan terjadilah

ketidaksetaraan gender. Hal ini tentu sangat merugikan kaum perempuan dan akan menghambat kaum perempuan untuk berdiri sama tinggi dan duduk sama rendah dengan kaum pria. Khususnya dibidang pendidikan, kaum perempuan dianggap harus mengalah bila dihadapkan kepada pilihan untuk maju kejenjang yang lebih tinggi.

Kesenjangan tingkat pendidikan yang terjadi antara anak perempuan dan anak laki-laki merupakan fakta yang masih ada 
di sebagian daerah di Indonesia. Ini tentu merupakan suatu hal yang harus ditelaah lebih jauh tentang faktor-faktor apa sajakah yang menyebabkan hal ini terjadi. Perlu pula diteliti lebih jauh dampak yang akan terjadi jika fakta ini dibiarkan berlarut-larut terjadi di negara kita serta solusi yang perlu diterapkan.

\section{Faktor-faktor Penyebab terjadinya Kesenjangan Pendidikan pada Perempuan}

Sebuah mediaonlinememberitakan bahwa Umiyatun Hayati Triastuti, seorang Staf Ahli Menteri Negara Perencanaan Pembangunan Nasional/ Kepala Bappenas, dalam sebuah acara Talk Show di Bandung menyatakan bahwa penyebab terjadinya kesenjangan gender adalah adanya nilai sosial serta budaya patriakal. ${ }^{12}$ Selanjutnya ia juga menyatakan bahwasebagian masyarakatdi Indonesiamasih menganut pemahaman agama yang bersifat parsial sehingga menyebabkan ketidakadilan dalam memperlakukan manusia menurut gendernya. Hal ini didukung oleh Meutia Hatta $^{13}$ bahwa kuatnya budaya patriarki menyebabkan pemikiran bahwa adalah kesiasiaan menyekolahkan anak perempuan ke jenjang yang lebih tinggi. Beliau menuturkan bahwa"setinggi-tinggi perempuan bersekolah, akhirnya masuk dapur juga. Pemikiran seperti ini tentu merupakan pemikiran yang sangat picik di era yang sudah semakin berkembang di masa ini. Paham inilah yang akan menjadikan bangsa kita jalan ditempat atau yang lebih buruk adalah semakin terpuruk ke dal am ketertinggalan.

Lebih jauh Mutia ${ }^{14}$ menyatakan beberapa faktor lainnya yang mengakibatkan seorang anak perempuan memiliki pendidikan yang lebih rendah dibandingkan anak laki-laki adalah sebagai berikut:1)A danyatradisi bahwa seorang anak perempuan adalah pengurus rumah tangga sehingga sebaiknya tidak dibebankan oleh pendidikan. 2) Walaupun ada kesempatan namun jika terbentur masalah biaya, maka anak laki-laki harus didahulukan dalam mengecap pendidikan. 3) Jika telah menikah dan punya anak, maka si perempuan harus menghentikan proses pendidikannya dengan alasan kepentingan keluarga.

Sementara wakil Ketua DPR RI-Melani Leimena-menyebutkan bahwa kaum wanita perkotaan telah mendapatkan kesetaraan gender diberbagai bidang, khususnyadibidang pendidikan, namun wanita-wanitadi pedesaan masih banyak mengalami ketimpangan dalam bidang pendidikan yang memang disebabkan oleh tradisi daerah setempat-wanita sebagai pengurus rumah tangga. ${ }^{15}$ Sedangkan sebuah artikel dari media online lainnya menyatakan bahwa adanya seterotipe di dalam masyakarat yang masih tertanam kuat tentang apa yang patut dan tidak sepatutnya dilakukan oleh seorang wanita, juga menjadi faktor penyebab terjadinya ketidaksetaraan antara pria dan wanita. ${ }^{16}$ Pendapat ini menekankan perbedaan antara pria dan wanita, bahwa ada hal-hal yang seharusnya tidak dilakukan oleh wanita. Bahwa hal-hal tersebut hanya bisa dan boleh dilakukan oleh kaum pria. Wanita dianggap lemah, wanita dianggap tabu, dan wanita dianggap hanya pantas melakukan pekerjaan rumah tangga hingga tidak memerlukan tingkat pendidikan yang sama tingginya dengan kaum pria.

Sedangkan Nursyam ${ }^{17}$ juga menyatakan beberapa point penting senada yang menjadi penyebab utama terjadi ketidaksetaraan gender di bidang pendidikan. Pertama, adanya pandangan secara agama bahwa kaum wanita merupakan bagian dari kaum pria. Hal ini berarti bahwa pria dikatakan menjadi seorang yang superior sedangkan wanita adalah 
kaum inferior yang berpjak kepada kaum pria adalah pemimpin bagi kaum wanita. Kedua, berdasarkan pandangan sosiologis yang menyatakan bahwa seorang wanita di segala hal ditempatkan di rumah. Sehingga fakta ini tidak mendukung wanita untuk perlu berpendidikan tinggi. Ketiga, adanya pandangan psikologis mengenai kedudukan wanita sebagai istri yang mendampingi suami tanpa membutuhkan pendidikan yang lebih. Hal ini didukung oleh pandangan baheula bahwa kawin muda lebih terhormat dibandingkan menjadi seorang perawan tua. Adanya semacam ketakutan bagi para orang tua jika anak perempuannya lama mendapat jodoh, yang jauh berbeda perlakuannya terhadap anak pria. Keempat, pandangan budaya masyarakat yang menganut paham bahwa perempuan bukanlah sosokmanusia yang memerlukan pendidikan yang lebih. Bahkan buruknya, perempuan dianggap sebagai pelengkap pria saja. Kelima, menurut pandangan ekonomi, ada banyak perempuan yang tidak melanjutkan pendidikan disebabkan oleh ketidakmampuan ekonomi. Sehingga ketika ada anak pria dan wanita maka, didahulukanlah anak pria untuk melanjutkan pendidikan ke tingkat yang lebih tinggi. Sedangkan perempuan segera dinikahkan untuk melepas beban ekonomi keluarga.

Prof. Dr. Arief Rahman, M.Pd.-Ketua harian Komisi Nasional Indonesia untuk UNESCO juga mengemukan lima faktor yang menjadi penyebab terhambatnya kaum perempuan untuk melanjutkan pendidikan ${ }^{18}$ :

1. Kultur yang menomorduakan perempuan Arief menyatakan, perempuan Indonesia memiliki semangat tinggi untuk meraih pendidikan tinggi, namun sebagian dari kaum perempuan masih sangat menjunjung kultur patriarki. Kultur inilah, yang membuat perempuan dinomorduakan untuk memasuki akses pendidikan. Sangat disayangkan, bahwa kultur ini diikuti dan diterima masyarakat luas sebagai hal yang pantas, bahkan bagi perempuan itu pribadi.

\section{Sistem struktur sekolah kurang} memberikan kesempatan bagi perempuan Momok tentang pendapat masyarakat bahwa perempuan tidak perlu sekolah tinggi-tinggi bahkan ironisnya “Pendapat yang mengatakan perempuan tak perlu sekolah tinggi menjadi virus yang masih menyebar di sekolah, dalam sistem struktur sekolah," lanjut Arief.

\section{Lemahnya kesetaraan gender}

Istilah Kesetaraan gender ternyata belum didukung oleh kebijakan-kebijakan

yang tercantum pada kelembagaan negara. Lemahnya kesetaraan gender ini memerlukan resolusi politik yang menopang dan mengusung ke-equal-an gender yang termaktub dalam kebijakan kelembagaan negara. "Peraturan di daerah misalnya, masih banyak yang belum mengusung kesetaraan dan keadilan gender dari segi gaji perempuan dan lelaki. Cuti kepada lelaki saat istri melahirkan juga belum diusung dalam peraturan daerah, padahal peran ayah dibutuhkan pada masa melahirkan," kata A rief.

4. Manajemen rumah tangga belum seimbang, perempuan lebih mengalah

Perempuan cenderung bersifat mengalah demi mengurus anak serta keluarga. Akhirnya, keinginan untuk meraih gelar S2 atau S3, misalnya, tertunda atau bahkan 
dibatalkan demi peran sebagai ibu. Arief menegaskan, dengan adanya manajemen rumah tanggayang lebih baik, perempuan dan Ielaki memiliki kesempatan yang sama. Baik dalam mengurus rumah tangga maupun dalam mengembangkan dirinya.

5. Kesepakatan pasangan yang melemahkan perempuan

Saat masih berpasangan, pada kasus tertentu, kata Arief, masih terdapat perempuan yang terbatasi untuk mengembangkan diri. Misalnya, pria akan menikahinya, dengan memberi syarat ia harus mengurus rumah tangga saja. Kesepakatan pasangan yang dibuat sebelum menikah, bahkan menjadi syarat menikah, lantas membuat perempuan terbatasi geraknya. Masalah semacam ini tidak lantas terjadi pada setiap orang, dan sifatnya berbeda setiap kasus. Prinsipnya, ada kesepakatan tertentu yang dibuat untuk perempuan yang kemudian membatasi ruang gerak dan kemandiriannya untuk berkembang. "Persoalan kesetaraan gender perlu diatasi tidak hanya dari sisi kultural, namun juga perlu ada kebijakan yang tertuang dalam struktur," jelas Arief.

Faktor-faktor yang menyebabkan ketidaksetaraan gender khususnya dibidang pendidikan yang terjadi di kalangan masyarakat kita saat ini sungguh merupakan sebuah rahasia umum. Hal ini tidak dipungkiri lagi bahwa pemahaman dan pemikiran di atas masih mewabah terutama dikalangan masyarakat ortodok yang masih sangat menjunjung tinggi budaya-budaya yang mendekati kepercayaan leluhur lama. Masyarakat yang masih menganut paham patriakat, dimana kaum perempuan adalah kaum yang lemah yang harus manut dan turut apa kata suami. Kaum perempuan tempatnya adalah dirumah serta tidak memerlukan pendidikan yang tinggi demi kelangsungan hidup berumah tangga.

Kebudayaan dan kepercayaan tentang anak perempuan yang harus mengalah dibandingkan anak laki-laki masih tertanam kuat di pemahaman masyarakat kita. Seperti yang dituliskan oleh Ike Herdiana ${ }^{19}$ bahwa ketimpangan gender disebabkan oleh adanya konstruksi sosial dan buadaya. Ditengah modernisasi yang semakin kuat, masyarakat kita masih saja memegang teguh mitos-mitos lama yang menyatakan kekuatan pria dan kelemahan wanita. Bahwa pekerjaan wanita tidak sepatutnya dikerjakan oleh pria, begitu juga sebaliknya. Paham-paham lama yang seperti inilah yang membuat ketidaksetaraan gender semakinj mengakar kuat di lingkungan masyarakat kita.

\section{Dampak Ketidaksetaraan Gender di Bidang Pendidikan antara Kaum Perempuan dan Kaum Laki-laki}

Adanya kesenjangan yang terjadi antara kaum perempuan dan kaum lakilaki khususnya dibidang pendidikan akan menimbulkan dampak yang sangat beragam. Berkaitan dengan perempuan sebagai sekolah pertama bagi anak-anak generasi penerus bangsa tentu menjadi sebuah warning bagi kita semua. Hal ini mengingatkan kembali kepada filosofi bahwa jika wanita pada suatu tatanan sosial itu tidak baik maka tidak baik pula anggota-anggota dari tatanan sosial tersebut. Berangkat dari filosofi ini perlu diketahui dampak apa sajakah yang dapat terjadi ketika kaum perempuan tidak terpenuhi kebutuhannya akan pendidikan. 
Sebuah penelitian membuktikan bahwa ketimpangan pendidikan pada kaum perempuan berdampak negatif terhadap persepsi dari orang tua terhadap anak. ${ }^{20}$ Orang tua yang berpandangan bahwa anak perempuan harus segera dinikahkan ketika usianya dianggap cukup, akan mewariskan persepsi kepada anaknya, bahwa seorang anak perempuan tidak perlu mengenyam pendidikan terlalu lama. Paradigma bahwa seorang anak perempuan seharusnya dirumah dan anak laki-laki yang harus bekerja diluar rumah berimplikasi bahwa seorang anak laki-laki harus berpendidikan tinggi untuk mendapatkan pekerjaan yang lebih baik. Merupakan hal yang lumrah ketika seorang anak perempuan dihentikan masa sekolahnya dikarenakan menikah. Hal ini tentu berdampak negatif ketika si anak belum siap mental untuk menikah.

Ketidaksetaraan gender juga dapat menimbulkan ketidakadilan, dalam hal ini dibidang pendidikan. Ketika terbentur masalah ekonomi, budaya masyarakat biasanya lebih mengutamakan anak laki-laki untuk diberikan pendidikan yang lebih tinggi dibandingkan anak perempuan. Seperti yang telah disebutkan sebelumnya bahwa budaya patriaki yang mengunggulkan kaum laki-laki menyebabkan kaum perempuan mengalami ketertinggalan di bidang pendidikan. Akibatnya banyak kaum perempuan yang mengalami putus sekolah sehingga tidak mampu untuk mendapatkan pekerjaan yang layak.

Lebih jauh sebuah laporan ${ }^{21}$ menyebutkan bahwa adanya ketidaksetaraan gender khususnya dibidang pendidikan, akan berdampak buruk terhadap kesejahteraan dan kesehatan baik bagi perempuan, lakilaki dan anak-anak. Serta berdampak pula terhadap kemampuan masyarakat tersebut dalam meningkatkan taraf kehidupan.

Ketidaksetaraan gender bidang pendidikan ini juga terkait kepada kurangnya produktifitas manusia, sehingga mengurangi prospek mengentaskan kemiskinan dan jaminan kemajuan ekonomi. Yang terburuk adalah adanya ketidak setaraan gender ini mampu melemahkan pemerintahan suatu negara yang tentu akan berdampak pada gagalnya efektifitas kebijakan pembangunannya.

\section{Solusi untuk Mendukung Kesetaraan Pen- didikan pada Perempuan}

Educational gender gap dapat mengubah bangsa ini menjadi semakin tertinggal. Perlu adanya kebijakan yang tegas dari pemerintah dan dukungan masyarakat setempat untuk menyelamatkan bangsa ini dari keterpurukan ketidak setaraan gender. Dibutuhkan solusi yang konkret untuk mendukung kesetaraan pendidikan pada perempuan. Postkotanews. commencatatpenjelasan MenegPP\&PA bahwa semestinya kebijakan pembangunan khusus nya untuk perempuan mengarah kepada tiga aspek: pendidikan, kesehatan, dan ekonomi. ${ }^{22}$ Hal ini dianggap penting berkaitan dengan tujuan besar yaitu untuk menyejahterakan keluarga.LaporanPembangunanBerperspektif Gender $^{23}$ menyatakan bahwa sebaiknya ada instansi tertentu yang memberikan hak dan kesempatan bagi laki-laki dan perempuan.

Sementara itu, Meneg Pemberdayaan Perempuan dan Perlindungan Anak menyatakan bahwa untuk mengatasi adanya ketidaksetaraan gender saat ini perlu dilakukan pemahaman sejak dini bagi anak dimulai di lingkungan rumah tangga. ${ }^{24}$ Lebih lanjut ia menyatakan bahwa jika perlu telah ditanamkan pada usia anak sekolah dasar sehingga dapat dipahami dan 
diaplikasikan dengan baik. Dan ternyata, departemen Pemberdayaan Perempuan sedang berkoordinasi dengan Departemen Pendidikan Nasional untuk mewujudkan penanaman pengetahuan tentang kesetaraan gender.

$\mathrm{Kono}^{25}$ menyebutkan solusi bagi ketidaksetaraan gender ini yakni dengan membuat undang-undang Perlindungan Perempuan dan UU yang tidak menyudutkan perempuan. Lanjutnya, para anggota legislatif harus membuat undang-undang yang tidak diskriminatif. UU yang harus menguntungkan kedua belah pihak; perempuan dan lakilaki. Disamping itu harus ada sosialisasi UU yang telah dirumuskan sehingga masyarakat dapat mengetahui ketidaksetaraan gender yang terjadi ditengah-tengah masyarakat kita. Ditambah lagi, bahwa harus ada pengintegrasian gender dalams etiap kebijakan publik yang dibuat dan harus tersebar di seluruh program serta kebijakan berbagai instansi pemerintah, organisasi kemasyarakatan dan agama.

Dalam laporan Perkembangan Pencapaian Tujuan Pembangunan Millenium Indonesia ${ }^{26}$ terdapat kebijakan dan program untuk meningkatkan kesetaraan gender di Indonesia; yaitu 1) A danya kebijakan untuk mewujudkan persamaan akses pendidikan yang bermutu dan berwawasan gender bagi semua anak laki-laki dan perempuan. 2) Menurunkan tingkat buta huruf penduduk dewasa terutama penduduk perempuan melalui peningkatan kinerja pendidikan pada setiap tingkat pendidikan, melalui sekolah maupun Iuar sekolah. 3) Pendidikan kesetaraan dan pendidikan baca tulis fungsional bagi penduduk dewasa. 4) Meningkatkan kemampuan kelembagaan pendidikan dalam mengelola dan mempromosikan pendidikan yang berwawasan gender.

Lebih Ianjut laporan tersbeut menyatakan strategi dalam menjalankan kebijakan di atas, antara lain:

1. Penyediaan akses pendidikan yang bermutu secara merata bagi anak perempuan dan laki-laki.

2. Penyediaan akses pendidikan kesetaraan bagi penduduk usia dewasa yang tidak dapat mengikuti pendidikan sekolah.

3. Peningkatan penyediaan pelayanan pendidikan bacatulisuntuk meningkatkan derajat melek huruf, terutama penduduk perempuan.

4. Peningkatan koordinasi, informasi dan edukasi dalam rangka mengarusutamakan pendidikan berwawasan gender dan

5. Pengembangan kelembagaan institusi pendidikan baik ditingkat pusat maupun daerah mengenai pendidikan berwawasan gender.

Semakin berkembangnya negara ini diharapkan mampu mengubah pemikiran penduduk Indonesia untuk lebih legowo menerima fakta bahwa pria dan wanita hanya berbeda secara fisik saja. Solusi diatas tentu diharapkan pula mampu menjadi sebuah titik tolak adanya kesetaraan gender terutama dibidang pendidikan.

\section{KESIMPULAN DAN SARAN}

Ketidaksetaraan gender yang masih saja berkembang terutama di negaranegara berpenghasilan rendah menjadikan perempuan tidak memiliki kesamaan

kesempatan bila dibandingkan dengan kaum laki-laki. Ketidaksetaraan gender yang terjadi 
diberbagai bidang kehidupan khususnya di Indonesia, seyogianya saling berkaitan satu sama lain. Kesenjangan yang terjadi dibidang pendidikan, ekonomi, sosial, serta budaya membuat kaum perempuan tidak mampu berkembang dan mengembangkan diri untuk menunjukkan aktualisasi diri mereka. Ketidaksetaraan gender terjadi disebabkan oleh berbagai macam faktor yang pada dasarnya berasal dari pemikiran yang ortodok dan parsial. Pemahaman patriakat yang tertanam dikalangan masyarakat kita bahwa wanita hanya bisa mengurus rumah saja menyebabkan keengganan bagi kaum perempuan untuk melanjutkan sekolah ke jenjang yang lebih tinggi. Bahkan pernikahan dan masalah biaya menjadi sebuah alasan untuk meninggalkan bangku sekolah. Hal ini banyak banyak terjadi di daerah pedesaan dan tempat-tempat terpencil. Sayangnya kesenjangan yang ada membuat dampak yang buruk bagi perkembangan bangsa dan negara. Rendahnya pendidikan kaum perempuan menjadikan mereka merasa tidak mampu untuk mendapatkan pekerjaan yang lebih baik, serta demi meningkatkan taraf kehidupan mereka. Yang terburuk adalah, adanya ketidaksetaraan gender berarti lemahnya sebuah pemerintahan negara.

Dari sini penulis menyarankan adanya perubahan pemahaman tentang kesetaraan gender di kalangan masyarakat kita di manapun. Hendaknya para orang tua mempunyai pengetahuan serta mengubah pola pikir terhadap kesetaraan gender diantara anak perempuan dan anak lakilaki. Memberikan kesempatan yang sama diantara anak-anak mereka, sehingga tidak ada perasaan yang berbeda pada diri anak perempuan. Bahwa anak perempuan dan anak laki-laki adalah manusia yang sama-sama memiliki kemampuan mengaktualisasikan diri. Sehingga sejak dini mereka belajar untuk tidak membeda-bedakan gender dan meiliki kemampuan menghindari diskriminasi gender.

\section{DAFTAR PUSTAKA}

Aby. Pendidikan Perempuan Indonesia Masih Memprihatinkan. Diunduh dari: http:/ / www.poskotanews.com/ 2012/ 04/ 24/ pendidikan-perempuan-indonesia-masihmemprihatinkan/

Akses Perempuan Terhadap Pendidikan, Lapangan Kerja, Dan Politik Terus Membaik. Di unduh dari: http:/ / www. pikiran-rakyat.com/ node/ 192937

Bentuk-bentuk Ketidakadilan Gender. 2013. Diunduh dari: http:/ / www . menegpp.go.id/ aplikasidata/ index. php?option=com_content\&view =categor y\&layout=blog\&id $=52 \&$ Itemid $=117$

Creswell, John. W. 2008. Educational Research: Planning, Conducting, and Evaluating Quantitative and Qualitative Research. New jersey: Pearson Education.

Dita Citra Putri. 2013. Perempuan dan Pendidikan. Diunduh dari: koran online. Kuningan news.com di unduh dari: $\quad$ http:/ / m.kuningannews.com/ detil. php?module=detail lberita\&id $=3011$

Fitri Gayatri. 2008. Faktor Dan Dampak Ketimpangan Pendidikan Perempuan Dalam Kehidupan Perempuan. Sebuah Penelitian.

Gay.L.R and Peter Airasian. 2002. Educational Research. Ohio: Prentice Hall.

H. A. Yunus, Drs., S.H., MBA. Filsafat pendidikan, cv. Citra sarana grafika. Bandung. 1999. Sumber: http:/ / 
furqanwera.blogspot.com/ 2012/ 12/ pengertian-dan-tujuan-pendidikansecara.html \#ixzz2ttc6wl7f

Ike Hardiana. Implementasi Ketidaksetaraan (Gender). 2012. Di unduh dari: http:/ / ikeherdiana-fpsi.web.unair.ac.id/ artikel detail-63796-Psikologi\%20PerempuanImplementasi \%20Ketidaksetaraan\%20 (Gender).html

Kesetaraan Gender di Tanamkan sejak Dini. Di unduh dari: $\mathrm{Http}: / /$ www.antaranews. com/ print/ 1261642235

Laporan Penelitian Kebijakan Bank Dunia Pembangunan Berperspektif Gender: Melalui Kesetaraan Gender Dalam Hak, Sumber Daya dan Aspirasi: Rangkuman. 2001. Washington: The World Bank.

Laporan Perkembangan Pencapaian Tujuan Pembangunan Millenium Indonesia. 2005. Diunduh dari: http:// www.undp.or.id/ pubs/imdg2004/ bi/ indonesiamdg_bi_goal3.pdf

Lima Masalah Perempuan Yang Urgen. Diunduh dari: http:/ / Www.Waspada. Co.Id/ Index.Php?Option=Com Content\&View =Article\&Id =133594:5Masalah-Perempuan-Yang-Urgen\&Catid =31:Perempuan\&/temid=99

Meutia Hatta Swasono. Potret Kebangkitan Perempuan Indonesia. $\mathrm{Di}$ unduh dari: $\quad$ http:/ / www.setneg.go.id/ index. php?option=com_content\&task=view\&id $=2260$ \&itemid $=219$

Nursyam,Prof.Dr.M.Si.PendidikanBagiKaum Perempuan. Di unduh dari: P.Todaro, Michael. Pembangunan ekonomi di dunia ketiga. 2003. Gelora aksara paratama.

Rangkuman Pembangunan Berperspektif Gender. 2002. Jakarta: penerbit dian rakyat
Redemtus Kono. Mengkritisi Fakta Ketidakadilan Gender. 2009. Diunduh dari: http:/ / blog.insist.or.id/ insistpress/ archives/ 1578

Riza Harahap. 2013. Melani : Perempuan Harus Menempuh Pendidikan Setinggi Mungkin. Di unduh dari: http:/ / www.antaranews. com/ berita/ 369975/ melani-perempuanharus-menempuh-pendidikan-setinggimungkin

Undang-undang no 12 tahun 2012. Diunduh dari: http:/ / riau.kemenag.go.id/ file/ file/ produkhukum/ faiz1360854336.pdf

UNICEF. Fact sheet on girls education in indonesia. Di unduh dari: http:// www. unicef.org/ indonesia/ girls_education_ fact_sheet_final_eng_1_.pdf

\section{Endnotes:}

1 H. A. Yunus, drs., s.h., mba. Filsafat pendidikan, cv. Citra sarana grafika. Bandung. 1999. Sumber: http:/ / furqanwera.blogspot. com/ 2012/ 12/ pengertian-dan-tujuanpendidikan-secara.html \#xzzZttc6wl7f

2 Undang-undang no 12 tahun 2012. Diunduh dari: http:/ / riau.kemenag.go.id/ file/ file/ produkhukum/ faiz1360854336.pdf

3 P.Todaro, Michael. Pembangunan ekonomi di dunia ketiga. 2003. Gelora aksara paratama.

4 UNICEF. Fact sheet on girls education in indonesia. Di unduh dari: http:/ / www.unicef. org/ indonesia/ girls_education_fact_sheet_ final_eng_1_.pdf

5 ibid

6 Rangkuman Pembangunan Berperspektif Gender. 2002. Jakarta: penerbit dian rakyat

7 ibid

8 Gay.L.R and Peter Airasian. 2002. Educational Research. Ohio: Prentice Hall.

9 Creswell, John. W. 2008. Educational research: planning, conducting, and evaluating 
quantitative and qualitative research. New jersey: pearson education.

\section{0 op.cit}

11 Bentuk-bentuk Ketidakadilan Gender. 2013. Diunduh dari: http:/ / www.menegpp.go.id/ aplikasidata/ index.php?option=com conten t\&view =category\&layout=blog\&id $=52 \&$ Item $\mathrm{id}=117$

12 Akses Perempuan Terhadap Pendidikan, Lapangan Kerja, Dan Politik Terus Membaik. Di unduh dari: http:/ / www.pikiran-rakyat.com/ node/ 192937

13 Meutia Hatta Swasono. Potret Kebangkitan Perempuan Indonesia. Di unduh dari: http:/ / www.setneg.go.id/ index.php?option=com_co ntent\&task=view\&id=2260\&itemid =219

14 ibid

15 Riza Harahap. 2013. M elani: Perempuan Harus Menempuh Pendidikan Setinggi Mungkin. Di unduh dari: http:// www.antaranews.com/ berita/ 369975/ melani-perempuan-harusmenempuh-pendidikan-setinggi-mungkin

16 DitaCitraPutri.2013.PerempuandanPendidikan. Diunduh dari: koran online Kuningan news. com di unduh dari: http:/ / m.kuningannews. com/ detil.php?module=detail berita\&id=3011

17 Nursyam, Prof. Dr.M.Si.Pendidikan Bagi Kaum Perempuan. Di unduh dari: http:/ / nursyam. sunan-ampel.ac.id/ ?p=871

18 Lima Masalah Perempuan Yang Urgen. Diunduh dari: http:/ / Www.Waspada. Co.ld/ Index.Php?Option=Com Content\&View =Article\&ld =133594:5-M asalahPerempuan-Yang-Urgen\&Catid=31:Perempua n\&ltemid $=99$
19 Ike Hardiana. Implementasi Ketidaksetaraan (Gender). 2012. Di unduh dari: http:/ / ikeherdiana-fpsi.web.unair.ac.id/ artikel_ detail-63796-Psikologi\%20PerempuanI mplementasi \%20K eti daksetaraan \%20 (Gender).html

20 Fitri Gayatri. Faktor Dan Dampak Ketimpangan Pendidikan Perempuan Dalam Kehidupan Perempuan. 2008. Sebuah Penelitian.

21 Laporan penelitian kebijakan bank dunia Pembangunan berperspektif gender: melalui kesetaraan gender dalam hak, sumber daya dan aspirasi: rangkuman.2001. Washington: The World Bank.

22 Aby. Pendidikan Perempuan Indonesia Masih Memprihatinkan. Diunduh dari: http:/ / ww w.poskotanew s.com/ 2012/ 04/ 24/ pendidikan-perempuan-indonesia-masihmemprihatinkan/

23 Op.Cit.

24 Kesetaraan Gender di Tanamkan sejak Dini. Di unduh dari: Http:/ / www.antaranews.com/ print/ 1261642235

25 Redemtus Kono. Mengkritisi Fakta Ketidakadilan Gender. 2009. Diunduh dari: http:/ / blog.insist.or.id/ insistpress/ archives/ 1578

26 Laporan Perkembangan Pencapaian Tujuan Pembangunan Millenium Indonesia. 2005. Diunduh dari: http:/ / www.undp.or.id/ pubs/ imdg2004/ bi/ indonesiamdg_bi_goal3.pdf. 